Article

\title{
World Citizens: Pathways for the Development of Eco-Citizenship in Higher Education
}

\author{
Hélène Domon
}

Department of Modern Languages and Literatures, California State University, Fullerton, CA 92831, USA; hdomon@fullerton.edu

Received: 22 July 2018; Accepted: 25 September 2018; Published: 28 September 2018

Abstract: It is time that universities reexamine what is meant by globalization. Contemporary scholars in the humanities, such as Peter Critchley, Noam Chomsky, Lewis Mumford, Elinor Ostrom, Charles Eisenstein, David Orr, Vandana Shiva, Naomi Klein, Lynn Margulis, Mustafa Tolba, Martha Nussbaum, Henry Giroux, Carolyn Merchant, Paulo Freire, Fritjof Capra, and Pier Luigi Luisi have aptly redefined the concept of "world" as a biological and cultural ecosystem. This paper seeks ways to integrate the theory and practice of eco-citizenship into various cross-disciplinary aspects of higher education, with a focus on curricular adjustments steered by World Languages and Cultures programs. It vests universities with a mission to engage themselves both as places of resistance against the neoliberal privatization of the commons and as the interactive, practical, analytical, and creative grounds needed for a healthy rebuilding of our global community. Through an assertive commitment in favour of eco-citizenship, universities will help clarify and resolve the strong conflict we are witnessing today between neoliberal orientations and an ecological exigency clearly delineated by scientific and humanistic scholarship.

Keywords: humanities; world citizenship; world languages; higher education; Peter Critchley; eco-praxis; ethics

\section{Introduction}

It is time that universities reexamine what is meant by globalization. Contemporary scholars in the humanities, such as Peter Critchley, Noam Chomsky, Lewis Mumford, Elinor Ostrom, Charles Eisenstein, Jean-Marc Ferry, David Orr, Vandana Shiva, Naomi Klein, Lynn Margulis, Mustafa Tolba, Martha Nussbaum, Henry Giroux, Carolyn Merchant, Paulo Freire, Fritjof Capra, and Pier Luigi Luisi have aptly redefined the concept of "world" as a biological and cultural ecosystem. This paper seeks ways to integrate the theory and practice of eco-citizenship into various cross-disciplinary aspects of higher education, with a focus on curricular adjustments steered by World Languages and Cultures programs. It vests universities with a mission to engage themselves both as places of resistance against the neoliberal privatization of the commons and as the interactive, practical, analytical and creative grounds needed for a healthy rebuilding of our global community. Through an assertive commitment in favour of eco-citizenship, universities will help clarify and resolve the strong conflict we are witnessing today between neoliberal orientations and an ecological exigency clearly delineated by scientific and humanistic scholarship.

"Global citizenship" is an old idea. In the fourth century BC, when asked where he came from, Diogenes of Sinope answered: "I'm a citizen of the world" (kosmopolitès). In modern times, world citizenship is often understood as some sort of sci-fi supranationality that would overrule (but also, paradoxically, enhance) the supremacy of nation-states as vectors for social, political, cultural, and economic identity. One can still buy a "World Passport" from the World Service Authority, a non-profit organization founded in 1954 that promotes World law, World government, and the sale of various 
fantasy World documents (World Service Authority 2018). The notion of global citizenship may one day find its actualization through the valuable, yet often arrested efforts of the United Nations. UN Goal 4.7 seeks to, "by 2030, ensure that all learners acquire the knowledge and skills needed to promote sustainable development, including, among others, through education for sustainable development and sustainable lifestyles, human rights, gender equality, promotion of a culture of peace and non-violence, global citizenship and appreciation of cultural diversity and of culture's contribution to sustainable development" (United Nations 2018). The 2017 Goal 4 Progress Report, however, acknowledges that "the lack of trained teachers and the poor condition of schools in many parts of the world are jeopardizing prospects for quality education for all" (United Nations 2018). While the United Nations organization remains a hopeful and often successful pathway toward implementing supranational laws and regulations, it continues intrinsically to posit the preeminence of national borders and identities. We must face a rather disheartening reality today: capitalism has been the superior force not only in imposing the liberal emancipation of markets throughout the world, but also in re-imagining globalism for the post-modern era. The global capital system continues to exert at once on its entrepreneurs, laborers, and consumers an endless fascination for a world which commercials and economic magazines portray as an easily reachable "global village", one that owes nothing to Marshall MacLuhan's claim for a "comprehensive awareness" of humans in spiritual connection and emotional familiarity with the world (MacLuhan 1989), and everything to the borderless and mostly heartless fantasy of accumulated wealth. How can we reach beyond?

I believe we must embed the notion of eco-citizenship within a radically renewed cultural, natural and ethical bedrock from which a more potent "world citizenry" will stem. This is expressed inspiringly by British philosopher Peter Critchley in his 2015 essay, Being at One: Making a Home in the Earth's Commonwealth of Virtue:

We need to take stock of our future prospects by developing a greater awareness of our place within the interlocking web of life. The lesson that we are embedded in the natural world needs to be reflected in our forms of governance, economics and civil society. By recovering the sense of our place in the world, rejecting pretensions of control, we come to develop an eco-citizenship that integrates our social and natural worlds. A global ethic is integral to that reconstruction of the ground upon which we stand. Such an ethic involves a political and institutional dimension. The idea that we are citizens in the commonwealth of life/virtue implies a biospheric politics. (Critchley 2015, p. 6)

Universities are caught in a contradiction between a corporate/political call, which imposes that they meet the demands of the "real" world by preparing workers and leaders for the offers of the capital system, and an ethical mission, which would have them educate citizens capable of steering the world toward a sustainable future, which itself remains to be clearly defined. They are also caught in a second contradiction between, on one hand, a commitment to protect the diversity of their student population and, on the other hand, the need to develop an overarching cohesiveness within and between populations. Insofar as diversity often manifests itself as a celebration of individualism, which, as a cultural theme, sustains the capital system itself, and insofar as cohesiveness opens pathways towards a new collective society that invites the end of capitalism and the birth of a unifying human identity, which some fear will threaten to erase the history of multiculturalism and class difference, we can see how these contradictions could add up and create tensions in curriculum and funding as much as in educational vision. This article seeks to resolve those tensions and fears and to posit a global ethical ground that can nourish essential human needs while respecting individual differences. Beyond the relativism of values brought about by 20th century philosophy, it is time for higher education institutions to secure the essential standards that can help citizens achieve a sense of global harmony, and to re-narrate humanity without endorsing any kind of totalizing "winners' narrative." We need to move beyond the great contemporary philosophical fear that perceives commonality as bound to revive or consolidate the political and religious totalitarianisms of the past. By now, we have all witnessed how, ultimately, the great "invisible hand" of the global market has come to supersede any 
other forms of world civism, tragically destabilizing our identities, epistemologies, and pedagogies as members of a human and natural collective. In other words, it is only by judiciously resolving the tensions between economic individualism and ecological collectivism-perhaps ultimately by reversing the epithets in order to create a harmonious balance between an "economic collectivism" and an "ecological individualism" - that we will rediscover the legitimate "commonwealth" delineated by a Plato or Rousseau. Only then can we activate, after centuries of dry scientific positivism, the world-bound ontology proposed by the great environmental humanists of our era. The means to resolve this conflict must be integrated into the heart of our university curricula, torn as they are currently between liberal orientations and an ecological vision still in quest of definition. This may mean reconciling the arts and humanities with politics, economics, social sciences, earth sciences, and engineering. It may mean transforming the great engines that pilot our educational models, such as merit, self-motivation, excellence, and competition, into new forms of interpersonal drives, such as mindfulness, generosity, and compassion. It may also mean remythologizing our conception of the world through literary, artistic, and cultural explorations that will directly prepare the civic minds of all students as they undertake scientific projects in other disciplines such as business or science.

Departments of World Languages and Cultures are ideally positioned in the academic landscape to foster the development of a greater eco-civic and biospheric awareness that can permeate the new curricular orientations of universities in the United States and abroad. New courses, degrees, study abroad programs, field trips, international exchanges and a wealth of various interdisciplinary projects can come together in lively ways to formulate and sustain a multi-faceted "eco-praxis" around the world. This article aims at describing the main principles of eco-citizenship, rooted in the widespread revalorization of the interaction between humans and their natural ecosystem. World Languages and Cultures programs have a key role to play not merely in teaching individual world cultures, but also in engaging students into a genuine reflection on what it means to belong to one world and to act from it, rather than upon it, as world citizens with common cores, emotions, wishes, needs, resources, paths and ideals that lie in full harmony within the fundamental and innately comprehensive purpose of life on earth.

\section{A New Challenge for World Languages and Cultures Departments}

World Languages and Cultures and Cultures departments, while very successful at sharing and teaching singular world cultures (French, Spanish, Japanese, etc.), directly face the eminent challenge of fostering a planetary identity for themselves and for students on their campus. Yet there are obstacles to overcome in order to achieve this objective.

First, an acute structural compartmentalization has often undermined their unity as departments. Whether they have decided to name themselves "World Languages and Cultures", "World Literatures", “Modern Languages" or, rather obsoletely, "Foreign Languages" ${ }^{1}$, World Languages and Cultures departments are typically composed of separate language programs that cooperate minimally in terms of curriculum. Language programs usually come together to define common "missions and goals" for the department and to seek departmental approvals for programmatic decisions, but retain an important degree of autonomy and separation in curriculum design (within, of course, national and state accreditation criteria as well as basic harmonization criteria for course content and numbering across the department). The complex structure and fragmented identity of these departments and the frequent insularity of their separate programs, which often exhibit marked cultural distinctiveness, unevenness in size, and competition for the funding of teaching units, release time, or new faculty positions, may create tensions that are well recognized by chairs and college deans. Such structural

1 That name is usually considered obsolete since most languages offered in those departments are native to a good number of U.S. students. Recently, the well-established CSU "Foreign Language Council" changed its name to the "World Languages and Cultures Council." 
and cultural fragmentation may not only obstruct the democratic and collegial process necessary to reach curricular decisions within these departments, but also prevent World Languages and Cultures faculty as a body to reach a "worldly" identity they would be best positioned to define and propagate on their campus. A quick survey of World Languages and Cultures department web pages reveals that their stated mission revolves around the theme of "diversity" rather than around "commonality," i.e., planetary cohesion and interconnection between the human and the natural world. My department's web page is a typical example, placing the emphasis on its "diverse programs" and the "varying needs" of students:

The [CSUF] Department of Modern Languages and Literatures offers diverse programs of language, cultural studies, linguistics, literature, and teacher education aimed at meeting the varying needs of today's students. (CSUF MLL 2018)

Most PhD-granting institutions have created distinct departments for single languages or families of languages. Harvard University, for example, offers an impressive array of World Languages and Cultures departments (Celtic Languages and Literatures, Classics, East Asian Languages and Civilizations, Germanic Languages and Literatures, Near Eastern Languages and Civilizations, Romance Languages and Literatures, Slavic Languages and Literatures). The 2007 Modern Language report on foreign language learning emphasized diversity and the reflexive relation between native and target cultures. Anchored in the valorization of national differences and cultural diversity, this binary-rather than holistic —approach to the world still guides teaching philosophies in most departments:

The language major should be structured to produce a specific outcome: educated speakers who have deep translingual and transcultural competence. [ ... ] The idea of translingual and transcultural competence places value on the ability to operate between languages. Students are educated to function as informed and capable interlocutors with educated native speakers in the target language. They are also trained to reflect on the world and themselves through the lens of another language and culture. They learn to comprehend speakers of the target language as members of foreign societies and to grasp themselves as Americans-that is, as members of a society that is foreign to others. They also learn to relate to fellow members of their own society who speak languages other than English. (Harvard Arts and Humanities Division 2018)

While arguably a central value in a world conceived as a set of relations between private individuals, cultures, or subcultures with discrete needs, it is possible that "diversity" obviates "commonality" and deflects the indispensable exploration of our collective being-in-the-world. As World Languages and Cultures departments seek to situate themselves more radically in the educational landscape as the carriers of a world vision that transcends divisions, they need to redefine the world as oikos (house) and instill into their pedagogy and public events the sharing of a genuine, fundamentally modern economics (oikonomia, shared house rules, ecology, eco-citizenry, eco-culture, "eco-poetics" (Pughe 2005)).

A second reason why World Languages and Cultures departments have typically remained compartmentalized and instrumentalized, rather than holistic and visionary, is that university administrators have attempted to confine them to a reductive, skills-oriented, utilitarian language teaching agenda designed to prepare students for "global competency", a notion defined in the following terms by Carol Conway, Director of the Southern Global Strategies Council:

"[Global competency is] the ability to be fluent in at least one other language, such as Spanish or Mandarin; fluency with e-commerce and the Internet; a well-versed knowledge of geography; and, maybe most important, some knowledge of the political and cultural history of one or two countries or regions outside of Western Europe." (Cited in Willard 2018) 
In the same NAFSA leaflet on "Global Competency", Jed Willard goes on citing CEOs from big companies who desire global competency from their workers:

"All major hiring companies need global citizens. Global sensitivities, global perspective, global insight; along with maturity and a capacity for risk-taking, are exactly the skills every major organization is looking for-in every industry."-Kevin Gill, Global Director of Staffing for Honeywell.

"In the financial world, cultural awareness and cultural adeptness are far more important than undergraduate major or existing skill sets [ ... ] These needs touch all industries, from banking to healthcare to engineering."-Jonathan Jones, Firmwide Campus Recruiting Director for Goldman Sachs." (Willard 2018)

Such an attempt at subordinating World Languages and Cultures to the business arena hinders the development of an independent eco-cultural interpretation of the world and prevents World Languages and Cultures departments from infusing a holistic philosophy into their missions and goals. Similarly, the 2007 Modern Language Association report (cited above) clearly prioritized a utilitarian form of communication that responded to business, national defense and security agendas:

"In the context of globalization and in the post-9/11 environment, then, the usefulness of studying languages other than English is no longer contested." (Ad Hoc Committee on Foreign Languages 2007)

Indeed, a "National Security Language Initiative" (aka the "Strategic Language Initiative") was launched by George W. Bush in 2006 to develop the foreign language skills of American students in "critical need" of foreign languages such as Arabic, Chinese, Russian, Hindi, and Persian. Brusquely realizing after 9/11 that foreign language learning was "useful" to protect the nation and that the United States suffered from a great scarcity of foreign language competency in comparison with other countries, the initiative was allocated USD 114 million in 2007 and USD 26.6 million in 2008 to expand programs from kindergarten level to university (Powell 2006). First and second-year courses in the languages spoken by the infamous nations of the "axis of evil" instantly flourished in universities around the country. For a few years, temporarily hired faculty members attempted to develop these programs into new minors and majors, most of which were soon abandoned and de-staffed as funding was reduced by our political and educational leaders. World Languages and Cultures departments have always been particularly affected by variations in people's interests for global affairs and ideas. Unfortunately, the current ideology, which seeks to reduce the scope of World Languages and Cultures to the development of communication skills for the sake of business and an array of other practical purposes, has led some administrators, students and even faculty members to question the usefulness of advanced literature/culture degrees taught in target languages. In a university system that lacks a clear planetary ethos and falls increasingly under the rule of for-profit utilitarianism, the very existence of the humanities has been questioned (Hanson 2014). In the past ten years, many undergraduate and graduate World Languages and Cultures Bachelor's Degrees and Master of Arts Degrees, deemed too costly, arcane, or useless, have been ruthlessly discontinued by university administrators who advocated maintaining only lower-division language courses (or possibly, low-unit minors and business concentrations) to meet the communicational needs of students from other majors. Ironically, while they harbored diversity as the driving force of their curriculum, World Languages and Cultures departments underwent, through the forced discontinuance of their small, diverse culture programs, the worst backlash against academic diversity ever known in the history of higher education, moreover in the fashionable name of sustainability. In France, a similar crisis in higher education prompted World Languages and Cultures faculty members from the Réceptions et Médiations des Littératures et des Cultures Etrangères et Comparées (RÉMÉLICE) research laboratory at the Universite d'Orléans to organize a captivating conference entitled "World Cultures Research and Teaching in Higher Education: What's the Use Today?" (RÉMÉLICE 2015) The conference led to 
important collaborations between international professors of English, Spanish, French, Czech, Polish, and German who stood in favour of revitalizing interdisciplinary and cross-departmental World Languages and Cultures studies by replenishing the study of a holistic "world culture" and resting this transformation on a theory and practice of eco-poetics, eco-citizenship and eco-literary criticism within and beyond the humanities. Other conferences around the world have been advocating the teaching of World Languages and Cultures, not as a useful appendix to business or professional programs, but as the core of what is probably the greatest mission of politics, education, ethics, economics, and society today: to define the contours of a "good" world, one which, rather than being composed of a sum of individualities, is felt, designed, lived and reflected upon as a single planetary home that intertwines all humans within an interconnected and wholesome life project. Outstanding projects in "Ecopedagogy", led by educators such as Paulo Freire, Moacir Gadotti, Angela Antunes, Richard Kahn, and Leonardo Boff seek to "re-educate "planetary citizens" to care for, respect and take action for all life." They have influenced World Languages and Cultures department all around the world, particularly in South America. They define "planetary citizenship" as follows: "Our lived reality is becoming globalized, we should globalize our sense of community, responsibilities and our commitments as well." (Practicing Freedom 2018).

A third aspect that may have kept World Languages and Cultures programs from fostering an overarching planetary culture is the long tradition of autonomous, single-language, century-based $\mathrm{PhD}$ programs that have formed their faculty. Few World Languages and Cultures professors are trained in multiple languages and cultures, although a multilingual ability has become a requirement or desired skill in most job descriptions (MLA Job List). Furthermore, few faculty members have received enough training in philosophy and environmental ethics to conceptualize and teach "world culture" organically. World Languages and Cultures students do deserve a holistic approach to the world that can later be incorporated into their teaching methodology at all levels, transcending the binary relation between self and other. There are admirable examples of curricular restructuration, for instance the "School of World Studies" at Virginia Commonwealth University, a holistic program with a genuine worldwide vision presented in these terms:

The School of World Studies is the intellectual and instructional center of international activities at VCU, and a major contributor to the study of the humanities at the university. The School encompasses disciplines which define what it means to be human - our ability to communicate (World Languages and Cultures), to build communities with distinct cultural practices (anthropology), to understand and interact with people/ideas different from our own (international studies), and to explore our place in the cosmos (religious studies). While exploring differences among cultures, languages, and belief systems, we also seek to find what we as humans have in common and to examine and celebrate the different contexts in which that humanity is expressed. (VCU School of World Studies 2018)

Interestingly, among many innovations, VCU also combined humanities and science into a single "College of Humanities and Sciences" and recently created an institute called "The School of Happiness." Another example is the unified "Department of Literature" at UC San Diego:

"The single Department of Literature gathers together a group of scholars, critics, and writers committed to research and debate on international and interdisciplinary issues surrounding the study of literature and culture. The organization of the Department of Literature is unique within the UC system in that it is neither a department of English nor a department of Comparative Literature as either is traditionally construed. Rather, from its beginning, the Literature Department at UCSD has aimed to be a department of world literatures and cultures within a single unit." (UCSD Department of Literature 2018)

A growing number of curricular reorganizations in World Languages and Cultures departments have been countering the utilitarian trend and preconizing new ethics. In the third section of this article, 
I will provide additional suggestions to develop a wholesome "world culture" in World Languages and Cultures departments, based on my own teaching practice and curricular experience at CSU Fullerton.

One important aspect in fostering a holistic approach in World Languages and Cultures is to overcome the arbitrary division between "the four language skills" (speaking, listening, reading, writing) and to approach language and culture as one entity. While most departments in the United States have already implemented holistic methodologies, French institutions seem to retain a noticeable separation of skills, especially in French as a Second Language (FLE) programs in which foreign students typically learn French through different skill courses with specialized instructors for each of the four skills, in a curriculum guided by the structure of DELF and DALF national exams (Production Orale, Production Ecrite, Compréhension Orale, and Compréhension Ecrite). There are valid arguments to separate the four language skills, and even to consider "culture" as an independent "fifth skill." The 2007 MLA report cited above, "Foreign Languages and Higher Education: New Structures for a Changed World", advocated the end of the two-tier system between lower-division instruction of language, generally by part-time faculty, and upper-division/graduate instruction of culture and literature, generally by full-time faculty, and suggested the introduction of culture and literature at the lower-division level. A virulent reaction to this report by Elizabeth B. Bernhardt, professor of German at Stanford and specialist in reading, aimed at conversely introducing advanced language study into the upper-division level:

While the Report calls for the literature faculty having "a hand in teaching language courses and in shaping and overseeing the content and teaching approaches used throughout the curriculum, from the first year forward" (p. 7), it provides no recommendation in the converse-the language teaching specialists having a hand in shaping the upper-level curriculum. The bitter irony here is that "language teaching specialists" on the current scene tend to be PhD holding academics with significant coursework in literature and culture as well as in applied linguistics. (Bernhardt 2010)

Both views concur in arguing that language and culture cannot be chronologically separated. They must be combined at both lower-division and upper-division/graduate levels. I would further argue that all courses at all levels should include six skills: the four language skills, a "fifth skill" (culture) as advocated in the past decade throughout the profession, and a new "sixth skill" (world citizenship).

\section{Defining World Culture and Eco-Citizenship}

Founding a genuine political and ecological vision with a planetary dimension demands academic, scientific and pedagogical tools that will allow the notion of "world culture" to inhabit not only the teaching of foreign cultures, but also an entire corpus of interdisciplinary programs in higher education. Such vision aims at forming "world citizens" and a global citizenship that transcends national and international borders. It delineates a new form of social contract, rationally based on an ample scientific research that views the earth as a single organism in terms of biology, biochemistry, environment, and physics. It promotes an active, living relationship between humanity and the world. It conceives global citizenship not simply as the acquisition of a transnational, transcultural and translingual passport, but as a collective sense of belonging to the earth. Following Diogenes' definition of "cosmopolitics" as a deep ethical fellowship, contemporary scholars in philosophy, ethics, psychology, environmental studies, engineering, international law, and politics all provide converging definitions of the "planetary consciousness" needed by our new global citizenry. The history of the "Global Citizenship" movement is excellently summarized in this article:

Global citizenship, in some contexts, may refer to a brand of ethics or political philosophy in which it is proposed that the core social, political, economic and environmental realities of the world today should be addressed at all levels-by individuals, civil society organizations, communities and nation states-through a global lens. It refers to a broad, culturally and environmentally-inclusive worldview that accepts the fundamental interconnectedness of all 
things. Political, geographic borders become irrelevant and solutions to today's challenges are seen to be beyond the narrow vision of national interests. Proponents of this philosophy often point to Diogenes of Sinope (c. 412 B.C.) as an example, given his reported declaration

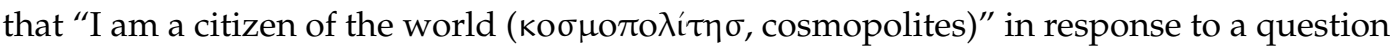
about his place of origin. A Sanskrit term, Vasudhaiva Kutumbakam, has the meaning of "the world is one family." [ ... ] Global citizenship identification [according to Reysen and Katzarska-Miller] then predicts six broad categories of prosocial behaviors and values, including: intergroup empathy, valuing diversity, social justice, environmental sustainability, intergroup helping, and a felt responsibility to act. (Global Citizenship 2018)

Rousseau emphasized that world citizenship is a form of "attachement," ${ }^{2}$ which is both an emotional bonding and a contractual sociality able to redeem the misère created by the tragic inauguration of private property. ${ }^{3}$ This attachment is not natural, but taught and learned as the result of an educational project, as Florent Guénard explains in his study of L'Émile:

La sociabilité n'étant pas naturelle, il n'y a aucune raison de penser que l'inégalité est naturelle: elle est politique, elle advient par nos institutions. Que l'homme soit asocial par nature a dans l'Émile un double enjeu: à la fois faire de la sociabilité un objet d'éducation et jouer sur cette asociabilité pour permettre à l'éducation, de manière générale, d'atteindre les fins qu'elle se fixe. La modernité se définit pour Rousseau dans cette absence de conditions politiques permettant la formation de citoyens qui se considèrent eux-mêmes comme des unités strictement fractionnaires.

Since sociability is not natural, there is no reason to think that inequality is natural: it is political, it happens through our institutions. That man is unsociable by nature has a double challenge in Emile: both to make sociability an object of education and to play on this asociability to enable education, in general, to achieve its ends. Modernity is defined by Rousseau in this absence of political conditions allowing the formation of citizens who consider themselves strictly fractional units. (Guénard 2009)

The Rousseauist educational tradition does not consider world citizenship as a natural quality of the human species as much as an educational objective. Universities today are adopting this objective as part of their stated mission toward world peace, happiness and a livable environment. At the same time, they should surpass the Rousseauist model, which yielded a subtle form of top-down professorial elitism and separated learners (Émile, the naturally "fractioned unit," as Guénard says) from their civic maitres. Marx suggested, in The Jewish Question, that world citizenship is a natural quality of all humans, however alienated it has come to be in the bourgeois system:

The real man is recognized only in the shape of the egoistic individual, the true man is recognized only in the shape of the abstract citizen. [...] Only when the real, individual man re-absorbs in himself the abstract citizen, and as an individual human being has become a species-being (Gattungswesen) in his everyday life, in his particular work, and in his particular situation, only when man has recognized and organized his "forces propres" as social powers, and, consequently, no longer separates social power from himself in the shape of political power, only then will human emancipation have been accomplished. (Marx 1844)

2 "C'est la faiblesse de l'homme qui le rend sociable; ce sont nos misères communes qui portent nos cœurs à l'humanité: nous ne lui devrions rien si nous n'étions pas hommes. Tout attachement est un signe d'insuffisance: si chacun de nous n'avait nul besoin des autres, il ne songerait guère à s'unir à eux. Ainsi de notre infirmité même naît notre frêle bonheur." Rousseau Jean-Jacques, Émile, Livre IV.

3 "Le premier qui, ayant enclos un terrain, s'avisa de dire: Ceci est à moi, et trouva des gens assez simples pour le croire, fut le vrai fondateur de la société civile. Que de crimes, que de guerres, de meurtres, que de misères et d'horreurs n'ê̂t point épargnés au genre humain celui qui, arrachant les pieux ou comblant le fossé, ê̂t crié à ses semblables: Gardez-vous d'écouter cet imposteur; vous êtes perdus, si vous oubliez que les fruits sont à tous, et que la terre n'est à personne." Rousseau Jean-Jacques, Discours sur l'Origine de l'Inégalité parmi les Hommes, 1755. 
According to Marx, our natural citizenship remains in us as our "forces propres," a power that we must repossess in reality as social power. It is most interesting that Marx considers political power as a disfigurement of the natural social power that lies at the core of the human species. Since we all carry this social power as part of our innate being, the role of education is not so much to teach world citizenship as to release it, and to organize this potential through reciprocal, participatory relationships. The classroom itself then becomes the terrain of a civic praxis, as Peter Critchley describes in Being at One:

This participatory conception of the world as a co-creation suggests possibilities for citizen knowledge, a knowledgeable citizen body that is capable of responding to and absorbing scientific knowledge whilst at the same time generating new knowledge from within the world of everyday experience. This is to present a view of citizens as both knowledge generators and assimilators. (Critchley 2015)

A planetary ethic will let knowledge, which by nature is mutual, unfold as citizenship within "the interlocking web of life." As an institution that both reflects and deconstructs institutional power, the university constitutes a crucial space for social life, conducive to the reconstruction of the civic ideal. Critchley sketches the inspiring silhouette of a new world citizenry anchored in ecology, cooperation and pluralism:

I build upon the ideal of an active, informed and involved citizenry to deepen and broaden the democratic basis for the ecological society, supporting a pluralistic way of life by which human beings as creative agents are able to determine, and seek to realise, environmental values together. Reconstruction requires the creation of appropriate institutions that are capable of taking effective action, of commanding popular support and of involving people as citizens. (Critchley 2015)

In this new perspective, the university itself becomes a fractal of the global village that Lewis Mumford delineated in his revolutionary 1961 essay The City in History:

The old separation of man and nature, of townsman and countryman, of Greek and barbarian, of citizen and foreigner, can no longer be maintained: for communication, the entire planet is becoming a village; and as a result, the smallest neighbourhood or precinct must be planned as a working model of the larger world. Now it is not the will of a single deified ruler, but the individual and corporate will of its citizens, aiming at self-knowledge, self-government, and self-actualization, that must be embodied in the city. (Mumford 1961)

Since it remains a public space (and even though it is being attacked precisely as such), the university can serve as a basis for the development of our eco-political community. Margaret Kohn, in Brave New Neighborhoods: The Privatization of Public Space, warns against the colonization of public space by private interests. What is threatened is our very own chance at building a world citizenry away from corporate rapture:

Public space plays an important role in fostering democracy by preserving opportunities for political speech and dissent and providing a shared world where we can potentially recognize one another as citizens. (Kohn 2004)

Critchley identifies the privatization of the commons as a strategy of fragmentation of the global citizenship that emanated from a prior, if not essential, public community:

The whole project [of privatization] has been about atomising the citizen body and preventing the individuals composing the demos from engaging in political action, from extending public associational space, and hence from creating a collective social power capable of checking, even subverting, the collective power of vested economic interests. The whole strategy has been about the expropriation of public resources and the colonisation of social affairs by the corporate form. (Critchley 2015) 
Noam Chomsky has long documented the indoctrination of our society and its submissiveness to a capitalistic system that triggers domestic and international conflict, poverty and wars for the sake of private interests. What makes this indoctrination all the more staggering is the fact that the propaganda that sustains it is carried out by the very class of highly educated media professionals and educators from whom we expected independent inquiry and guidance. Universities today, and World Languages and Cultures departments in particular, must ask themselves whether they are authentic spaces of constructive analysis shaping a "good living" in the world, or merely the semi-public arenas used by the "commissars" of a system that suppresses a genuine, forward-looking reflection on global kinship. As Chomsky said already in 1984:

Our system differs strikingly from, say, the Soviet Union, where the propaganda system literally is directed and controlled by the state. We're not a society which has a Ministry of Truth which produces doctrine which everyone then must obey at a severe cost if you don't. Our system works much differently and much more effectively. It's a privatized system of propaganda, including the media, the journals of opinion and in general including the broad participation of the articulate intelligentsia, the educated part of the population. The more articulate elements of those groups, the ones who have access to the media, including intellectual journals, and who essentially control the educational apparatus, they should properly be referred to as a class of "commissars." That's their essential function: to design, propagate and create a system of doctrines and beliefs which will undermine independent thought and prevent understanding and analysis of institutional structures and their functions. (Chomsky 1984)

The university is the archetype of the public association defined by Critchley as part of the "commons," which ideally enables its members to flourish as "active eco-citizens" empowered to design and implement a desirable social order through a communal teaching-learning experience:

In terms of environmental ethics and politics, we become active eco-citizens working in concert, a diverse association of experimental learners able to identify relevant facts and resolve problems, free of the influence of distorting forces. The true and the good emerge through a social intelligence within a community of inquirers, something which serves to form the bedrock of a democratic social order. (Critchley 2015)

Critchley points out that the mutuality of the learning process embraces the very pattern of democratic praxis:

Human agency therefore possesses a reflexive character in that knowledgeability stands at the heart of the ongoing process of externalisation, appropriation and reappropriation of human powers at a higher level of development. That is to say, human beings, through their creative praxis, are involved in a continuous interplay in which power is first objectified and then reclaimed as a social and human power against the abstracting effects of appropriating systems. (Critchley 2015)

World Languages and Cultures courses can indeed become primary grounds for this emancipatory and reflexive process because they naturally foster a binary reciprocity between native vs. target cultures. By reflecting on society from humanity's most intimate, yet diverse cultural expressions, they are ideally positioned to bind the creation of knowledge with its practice and to engage students in the re-appropriation of social power. World Languages and Cultures students actively take part in a university connected to a universe that they help "co-create." As a global "citizen body", they simultaneously assimilate and generate the knowledge of the world, as expressed by Critchley:

This participatory conception of the world as a co-creation suggests possibilities for citizen knowledge, a knowledgeable citizen body that is capable of responding to and absorbing scientific knowledge whilst at the same time generating new knowledge from within the 
world of everyday experience. This is to present a view of citizens as both knowledge generators and assimilators. (Critchley 2015)

The study of "living languages" (langues vivantes) thus becomes the active, co-creative, lively hub of world citizenship. Once we understand this challenge intellectually, emotionally and even sensuously through the close contact with another language-culture as well as within a reclaimed university space, we become ready for new teaching pedagogies that are motivated by the overarching goal of finding happiness on Earth.

\section{From Theory to Practice}

Beyond the classroom, teachers of World Languages and Cultures have a responsibility to promote the concept of world citizenship in public spaces on and off campus. World Language departments today are making innumerable efforts in that direction. I would like to suggest just a few paths, mostly based on my own practice at California State University, Fullerton.

In order to develop a holistic pedagogy, we have opted to go beyond the arbitrary division between language skills and to approach language and culture as an entity. All courses at all levels in California State University Fullerton's French program include the development of the six skills (reading, writing, speaking, listening, target culture, and world culture as defined here). Courses have become multidisciplinary, with a carefully designed articulation of cultural contents between levels. We have placed an emphasis on daily life in French-speaking regions of the world during the first semester (FREN 101); on travel and discovery of the francophone world during the second semester (FREN 102); on life in the city, with an introduction to urban studies and green cities, during the third semester (FREN 203); on nature and the countryside, with an introduction to ecology and environmental studies, during the fourth semester (FREN 204); on globally reaching themes in our upper-division variable-topic course in "Advanced Culture" (FREN 435T), such as "City and Country", "The Outsider", "Culture and Dance", etc. Every course includes oral, written, cultural and global competency modules that are tightly imbricated into each other.

CSUF's French program is currently participating in the revisions of General Education courses, which creates a fruitful interaction between language programs and gives hope that the concept of eco-citizenship will take root at the core of academic departments and Cultural Diversity categories.

As an example, these excerpts from the syllabus for the GE French Literature survey course, FREN 375 , will underline the inclusion of the "sixth skill," eco-citizenship, in both content and assessment:

This course explores French culture and society through literature. [ ... ] Beyond gaining a panoramic knowledge of French literature, this course helps students appreciate who they are as global citizens of a worldwide humanity. They recognize literature as an essential gateway for the in-depth understanding of culture that is indispensable for their personal, civic, humanistic and professional development. [ ... ] This course will connect the knowledge of French literature with various disciplines in the humanities such as history, art, music, religious studies, philosophy, sociology, psychology and linguistics. [ ... ] By studying French literature throughout the ages and into the contemporary era, students analyze complex humanistic issues that have transformed France's social structures and cultural representations. They appreciate the solutions French people have sought to problems and challenges, whether in contrast or similarity with the American society. For example, current issues of environmental awareness, ecology and ethics, such as the concept of "degrowth," become linked to the search for a soulful connection with nature in Guillaume d'Aquitaine and Chrétien de Troyes (week 2), Du Bellay (week 3), Chateaubriand (week 11), Rimbaud (week 12) and Ponge (week 14). Structures of oppression that dominate feudal society (week 2), Ancien Régime (week 5), capitalistic exploitation (weeks 10, 12), consumerism (week 13), colonialism (week 14) or patriarchal society (week 15) are vividly analyzed, particularly in novels and dramas, and students come to assess the importance of revolutions-republican, 
proletarian, indigenous, feminist-as attempts and solutions to emancipate human beings. [ ... ] Finally, a fresh psychological plea in favor of a healthy balance of emotions and an unearthing of each person's élan vital is made via the study of Montaigne (week 3), female writers Louise Labé, George Sand, Marguerite Duras (weeks 3, 12,13) and Surrealist poets Breton, Eluard, Aragon, Apollinaire and Senghor (week 13). [ . . . ] Students compare cultural practices of French people with those of Americans. For example, students compare and contrast French and American viewpoints on sexuality (week 15), the role of women in family and society (weeks 6-7), the expression of emotions (weeks 5, 12), the communion with nature (weeks 2,11) and the relationship of citizens with the state (weeks 9-12). Students also understand the relationship between and within various Francophone cultures (Senegalese, Haitian, Swiss, Quebecois, Moroccan, etc.) and the intercultural connections that derive from French colonialism (weeks 9, 15). [ ... ] Students evaluate the importance of major movements in French cultural history, such as humanism (week 3), the Enlightenment (weeks 9-10), political or feminist revolutions (weeks 10, 15), existentialism (week 13), psychoanalysis and surrealism (week 14), impressionism and symbolism (week 12), in relation to American cultural history and their own sense of identity or relationship with others. [...] Students who have successfully completed this course are able to [...] write short compositions, chosen from over forty topics, and a full-length essay in French (12-16 pages) in which they build their own world vision as influenced by their reading and analysis of French literature; present this vision to their classmates by using PowerPoint as a creative pedagogical tool with images, music and texts; elaborate their own research focus drawn from their personal learning goals by reshaping their compositions and PPT presentation toward a final essay. (Domon 2016)

Literature anthologies with a world vision are difficult to find. The French anthologies I reviewed for inclusion in this syllabus mainly contain dark, pessimistic texts, from Villon's "Ballade des Pendus" to Chateaubriand's stormy autumnal walks, from Zola's worst depictions of miners in Germinal to Sartre's L'enfer, c'est les autres or Annie Ernaux's and Houellebecq's contemporary wanderings in a soulless world. However, these same authors, as well as others (in particular, women authors or Francophone writers often discarded from anthologies and ignored by literary history), have also written remarkable texts with a highly positive vision of humanity. I chose one of the anthologies (Français Littérature, Nathan, 2011, edited by Desaintguislain) for its nice presentation and historical introductions. Among its hundreds of texts presented across centuries of French literature, I focused my analysis on 40 texts that contain seeds for an inspiring world. I eliminated the tragic and absurdist classics (or only passingly cited them in my literary history clusters). It felt liberating to break from the canonical gloom imposed on us by an aging 20th century literary criticism and to retrieve the joy of literature as it expresses constructive social, natural and emotional inquiries. I also let go of the typically French essay prompts for dissertation and commentaire composé included in the anthology, which tend to restrict students' literary explorations to formal descriptions, textual analysis and character categorization. Instead, I presented composition topics that prompt students toward a deeper humanistic and ecological reflection, such as:

(1) What is the relationship between love and nature?" Analyse Guillaume d'Aquitaine, "A la douceur du temps nouveau."

(2) "Communion or Hybris: What is the relationship between humans and the world?" Analyse Chrétien de Troyes, "Yvain."

(3) "What is simplicity?" Analyse Du Bellay, "Heureux qui comme Ulysse."

(4) "To what extent is poetry an offering?" Analyse Ronsard, "Comme on voit sur la branche."

(5) "Does the wheel of emotions guide us toward love?" Analyse Louise Labé, "Je vis, je meurs."

(6) "What is the relation between natural soul and social discourse?" Analyse Molière, "L'École des Femmes." 
(7) "Beyond suffering and exploitation, what can we hope for?" Analyse La Fontaine, "La Mort et le Bûcheron."

(8) "By what means can literature fight injustice?" Analyse Montesquieu, "De l'Esprit des Lois."

(9) "How can we build equality among humans?" Analyse Rousseau, "Discours sur l'origine de l'Inégalité."

(10) "In what way are nature and humans interconnected?" Read Chateaubriand, "René."

(11) "How does the human bond transcend death?" Analyse Hugo, "Demain dès l'aube" and Baudelaire, "Parfum exotique" and "La Mort des amants."

(12) "In what ways are humans interconnected?" Analyse Verlaine, "Mon rêve familier" and "Romance sans paroles."

(13) "To what extent is dawn/sunrise a phenomenon that is both internal and external?" Analyse Rimbaud, "Aube"s

(14) "In what way is humanity a flux/flow?" Analyse Apollinaire, "Sous le pont Mirabeau."

(15) "What are the psychoanalytical dimensions of the human bond?" Analyse Breton, "Clair de Terre."

(16) "In what way are humans guided and interconnected by the wheel of emotions?" Analyse Eluard, "L'amoureuse."

(17) "What are the different forms of the vital rhythm?" Analyse Senghor, "Chants d'Ombre."

(18) "To what extent is language related to the world?" Analyse Ponge, "Le lézard."

(19) "In what way are differences between men and women cultural rather than natural?" Analyse Simone de Beauvoir, "La Force des Choses."

(20) "To what extent is nature a source of emancipation?" Analyse Chraibi, "La Civilisation ma mère." (Domon 2016)

To answer these questions, students write short paragraphs before each class, then choose eight of the questions as composition topics, which they compile again in their PPT presentation and final essay, thus building a project throughout the semester that manifests their personal path as well as the input from their classmates and instructor in our common search for humanistic, planetary answers. Students in their evaluations for this course have expressed enthusiasm for their learning experience. I also have learned a lot from them as I continue my personal exploration of eco-citizenship through literature.

We also redesigned our upper-division curriculum. Our fourth-year literature program, which used to be organized by centuries, now offers three interdisciplinary courses: FREN 470, Literature and Power; FREN 471: Explorations of the Self; and FREN 472: Philosophical Explorations in French Literature. These courses help students connect literature with politics, psychology and philosophy. We created a new variable topic course in Advanced Culture (FREN 435T) that allows instructors to design their own path of inquiry, as well as a capstone seminar (FREN 485) in which students synopsize their trajectory, define a personal research path for the future, and learn how to share with others a 40-page semiotic project. We also included an eco-civic dimension in Language and Linguistics courses through redesigned syllabi in creative writing (FREN 408), translation (FREN 409) and linguistics (FREN 466). Finally, we proposed new departmental courses, such as "Global Issues in World Cinema" (to be co-taught in English with films in subtitled original languages) to enable our department as a whole to bring a fresh worldview to the CSUF campus.

Beyond curriculum, other activities foster the eco-civic project by connecting the university with the local off-campus community. For example, in 2009 we created The Left Bank of Southern California, a transdisciplinary Meetup group that currently has over 1800 members, about half of whom are faculty and students from CSUF. Its goal is deeply political in the Socratic sense of polis, without affiliation to any party. Gathering those who "wish to enjoy nature, celebrate life, expand peace, and engage themselves in social justice activism, locally and globally" (The Left Bank of Southern California 2018), the group is centred around an array of activities such as hiking and camping in Southern California, acoustic music jams, drum circles, coffee breaks (somewhat reminiscent of "Rive Gauche" café life in 
Paris), movies, concerts, parties, political and environmental activism, therapy exchange, workshops and lectures. The group is also a registered student association at CSU Fullerton and organizes regular "World Workshops" that gather faculty, students, artists, speakers and community members in an amphitheater to discuss contemporary global issues, from politics to education, history and ecology ("We are One," "Living with Earth," "Gleaners and Recyclers," etc.). Through these workshops, the campus has become a welcoming place for anyone willing to participate in a wider civic community and speak up on an issue:

Give a talk! Anyone is welcome to submit a proposal for a 10-min presentation on this topic. You do not need to be an expert, a teacher or a published writer-just an informed citizen of the Earth who would like to provide insights. (The Left Bank of Southern California 2018)

The experience of meeting people through a civic encounter that casually transcends institutional borders has been enriching for all of us and has helped us reclaim the campus and many other places in Orange County as public commons.

The eco-civic project can also attain an international level through the creation of exchanges and partnerships. We have proposed a Master's degree in French Studies that would gather students in three countries, France, California, and Togo. This degree would integrate the theory and practice of French-language literature and film with world citizenship and ecology. It would balance online technology and face-to-face pedagogy by combining online courses with summer stays in the three countries. International exchanges are ideal to strengthen a civic world.

Social networks also enable people to weave amazing connections across the world. I created a Facebook page called "Femmes Vertes-Green Women." (Green Women 2018). This art and photography page shares positive, active, independent, happy, natural images of women and girls across the world, in an attempt to deconstruct hegemonic structures that still weigh so heavily on women's shoulders. It is important to reconnect social networks with real-life encounters. For example, I plan to organize a World Workshop on campus on the theme "Green Women" in which the Facebook page's photos will become a visual support for a local creative writing and poetry reading workshop.

These are just modest examples of small steps that can be taken by each member of a university to bring about a healthier, happier sense of world citizenship. I will end this article with another quote by Peter Critchley, whose original and complex philosophical work (a gigantic corpus of over 60 books mostly published in free access in a fervent parti pris in favour of civic emancipation-see (Critchley 2018)) is being read by millions of readers around the world:

"I want to outline the contours of a 'civic environmentalism' which values the contribution of local, community-based movements to democratic politics and identifies the citizen members of the ecopolis as environmental stakeholders. This places the emphasis upon an active citizenship and points in the direction of a society with extensive public spaces and participatory structures. Set in the context of natural relations, this produces a concept of the eco-public or Ecopolis. This is to define democracy in terms of a genuine representation of the views and interests of all members of the ecological society, a society that is equitable, just and sustainable in its practices, social relations, decisions and policies. (Critchley 2015, p. 379)

Conflicts of Interest: The author declares no conflict of interest.

\section{References}

Ad Hoc Committee on Foreign Languages. 2007. Foreign Languages and Higher Education: New Structures for a Changed World. Profession, 234-45, Modern Language Association. Available online: https: / /www. mlajournals.org/doi/abs/10.1632/prof.2007.2007.1.234 (accessed on 1 September 2018).

Bernhardt, Elizabeth B. 2010. A Reaction to the 2007 MLA Report. Reading in a Foreign Language 22: 1-4. Available online: http:/ / nflrc.hawaii.edu/rfl/January2010/articles/bernhardt.pdf (accessed on 1 September 2018).

Noam Chomsky. 1984. Politics and Language. In Language and Politics. Edinburgh-Oakland: CK Press. 
Critchley, Peter. 2015. Being at One: Reason, Nature and Society. San Francisco: Academia.edu. Available online: http:/ / mmu.academia.edu/PeterCritchley (accessed on 1 September 2018).

Critchley, Peter. 2018. Being and Place. Available online: http:/ / pcritchley2.wix.com/beingandplace (accessed on 1 September 2018).

CSUF MLL (CSUF Department of Modern Languages and Literatures). 2018. Available online: http://hss. fullerton.edu/mll/ (accessed on 1 September 2018).

Department of Literature (University of California San Diego). 2018. Available online: http:/ /worldstudies.vcu. edu/ (accessed on 1 September 2018).

Domon, Hélène. 2016. FREN 375 Syllabus: Explorations in Literature. Available online: https:/ /www.academia. edu/12932600/FREN_375_Syllabus_Explorations_in_French_Literature (accessed on 1 September 2018).

Femmes Vertes-Green Women. 2018. Available online: https://www.facebook.com/FemmesVertes/photos_ stream (accessed on 1 September 2018).

Global Citizenship. 2018. Available online: https://en.wikipedia.org/wiki/Global_citizenship (accessed on 1 September 2018).

Guénard, Florent. 2009. Devenir sociable, devenir citoyen: Émile dans le monde. Archives de Philosophie 1: 9-29. Available online: https:/ / www.cairn.info/revue-archives-de-philosophie-2009-1-page-9.htm (accessed on 1 September 2018).

Hanson, Victor Davis. 2014. The Death of the Humanities. Defining Ideas, January 28.

Harvard Arts and Humanities Division. 2018. Available online: http://artsandhumanities.fas.harvard.edu/ pages / we-are (accessed on 1 September 2018).

Kohn, Margaret. 2004. Brave New Neighborhoods: The Privatization of Public Space. London: Routledge.

MacLuhan, Marshall. 1989. The Global Village: Transformations in World Life and Media in the 21st Century. Oxford: Oxford University Press.

Marx, Karl. 1844. The Jewish Question. Available online: https://www.marxists.org/archive/marx/works/1844/ jewish-question/ (accessed on 1 September 2018).

Mumford, Lewis. 1961. The City in History. Harmondsworth: Penguin Books.

Powell, Dina. 2006. National Security Initiative. Available online: https:/ /web.archive.org/web/20080306151344/ http:/ /www.state.gov/r/pa/prs/ps/2006/58733.htm (accessed on 1 September 2018).

Practicing Freedom/Ecopedagogy. 2018. Available online: http://www.practicingfreedom.org/offerings/ ecopedagogy/ (accessed on 1 September 2018).

Pughe, Thomas. 2005. Réinventer la nature: Vers une éco-poétique. Études Anglaises 58: 68-81.

RÉMÉLICE. 2015. "Recherche et transmission des cultures étrangères: Quelle utilité dans l'université d'aujourd'hui?" Centre de Recherches en Réceptions et médiations de littératures et de cultures étrangères et comparées. Université d'Orléans. Available online: http:/ / www.univ-orleans.fr/remelice/11-13-juin-2015recherche-et-transmission-des-cultures-\%C3\%A9trang\%C3\%A8res-quelle-utilit $\%$ C3\%A9-dans-lun-0 (accessed on 1 September 2018).

School of World Studies (Virginia Commonwealth University). 2018. Available online: http:/ / worldstudies.vcu. edu/ (accessed on 1 September 2018).

The Left Bank of Southern California. 2018. Available online: http:/ /www.meetup.com/TheLeftBank/ (accessed on 1 September 2018).

United Nations. 2018. Goal 4, “Sustainable Development". Available online: https://sustainabledevelopment.un. org/sdg4 (accessed on 1 September 2018).

Willard, Jed. 2018. Global Competency. NAFSA Association of International Educators. Available online: https://www.nafsa.org/_/File/_/global_competency_2.pdf (accessed on 1 September 2018).

World Service Authority. 2018. Available online: http:/ / www.worldservice.org/docpass.html?s=1 (accessed on 1 September 2018).

(C) 2018 by the author. Licensee MDPI, Basel, Switzerland. This article is an open access article distributed under the terms and conditions of the Creative Commons Attribution (CC BY) license (http://creativecommons.org/licenses/by/4.0/). 